\section{'Sell the message of research', Europe's cell biologists urged}

[BOLOGNA] European scientists should talk more about the importance of their work to both the public and politicians - if they are to be as successful in attracting funding as their colleagues in the United States.

This was the message transmitted by some of Europe's top cell biologists at a meeting of the European Cell Biology Organization (ECBO) in Bologna earlier this week.

According to Jacopo Meldolesi, head of neurobiology at the DIBIT research institute in Milan, European scientists are traditionally reluctant to band together and lobby politicians - particularly the European parliament - about the importance of basic research.

Meldosi says this is partly because the scientific communities are fragmented along national lines. Many scientists believe that a lack of lobbying force has eroded the role of basic research in the European Union's Framework programmes of research.

Last month, for example, at a meeting organized by Euroscience, the 'grass roots' association of European scientists, Members of the European Parliament criticized scientists in general for a tendency towards 'renationalization', and for not getting together and lobbying alongside industry and pressure groups such as Greenpeace (see Nature 398, 646; 1999).

Kai Simons, senior scientist at the European Molecular Biology Laboratory in Heidelberg, says that political lobbying is one of the aims of the newly formed European Life Sciences Organization (ELSO). This body is intended to take over from $\mathrm{ECBO}$, a federation of national societies, which has failed to attract large numbers to its annual meetings (see Nature 393, 615; 1998).

Despite its strong scientific programme, fewer than 900 scientists attended the meeting in Bologna. This is in contrast to meetings of the American Society for Cell Biology, which regularly attract 10,000 participants.

Simons hopes for up to 4,000 participants at ELSO's first meeting in Geneva next year. The organization is being modelled on the American society, he said. Its meetings will be cheap to attend, and it will also organize political lobbying, "but only if we get the mandate from members to do so".

Peter Rigby, director of the Chester Beatty Cancer Research Institute in London, says that scientists who are funded by charities should talk not only to politicians but also to the street collectors for those charities. The latter "need to know how the money is spent - even if the concepts are hard to put across - in order to keep up their motivation", Rigby says. Alison Abbott

\title{
US stem-cell pioneers buy 'Dolly' cloning company
}

[WASHINGTON] The US biotechnology company that financed the isolation of human embryonic stem cells has joined forces with the cloners of Dolly the sheep in a bid to combine the two technologies and speed the development of therapies for degenerative diseases.

Geron Corporation of Menlo Park, California, which announced the stem-cell work last year, said last week that it has bought Roslin Bio-Med, a company that was set up by the Roslin Institute, near Edinburgh, to develop its cloning technology (see Nature 396, 104; 1998).

The price was 2.1 million shares of Geron stock — worth about $\$ 26$ million at the time of the agreement. Geron will spend an additional \$20 million in the next six years funding research at Geron Bio-Med, as the renamed company is called.

In addition to the purchase price, the Scottish institute will continue to benefit from royalties from new intellectual property arising from the research funded by Geron, $\$ 4$ million of which will go to Roslin's animal genome research.

The research to be conducted by Geron Bio-Med aims to unravel how the cytoplasm of an egg 'reprogrammes' an adult cell nucleus, and to confer the same ability on a store of generic, enucleated cells that are not eggs. The goal is to circumvent the need for human oocytes as recipient cells in the cloning process, so avoiding both the ethical questions surrounding the cloning of human embryos, and the practical obstacle of a shortage of human oocytes.

The ultimate goal, according to Thomas Okarma, Geron's vice-president of research and development, is to inject a patient's own DNA into such a 'generic reprogramming cytoplast', then to direct the cell created in this way to form the tissue that is needed. In Parkinson's disease, for example, these would be dopamine-generating neurons. Because a patient is his or her own DNA donor, rejection should be avoided.

Geron has already cloned critical parts of human telomerase, an enzyme that allows cells to keep replicating beyond the time they would naturally have stopped - an important capability if transplanted cells are to replace those that have died or are not functioning properly.

"There is incredible synergy under one roof now with these three technologies, and with the collaboration with the Roslin Institute, which is obviously the premier animal genomics centre of the world," says Okarma.

"We feel that [the Geron-Roslin partnership] will begin to open doors towards

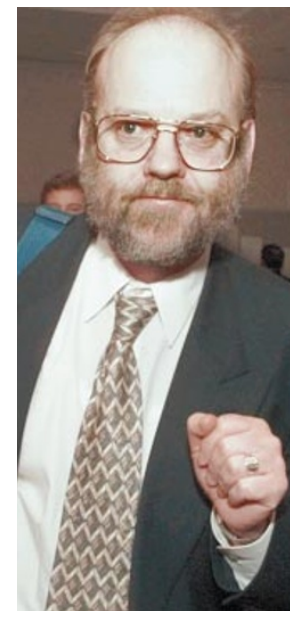

Wilmut: seeking to reprogramme cells.

division at the Roslin Institute.

cell-based therapies for a whole variety of degenerative diseases," says Ian Wilmut, the Roslin Institute scientist who cloned Dolly, and who will be chief scientific officer for Geron Bio-Med.

"The long-term aim is to reprogram human cells without using eggs or creating embryos," says Wilmut. He will run the research effort with John Clark, head of the molecular biology

Some remain sceptical about the feasibility of producing healthy cells - or animals by cloning, and so doubt that the GeronRoslin collaboration will succeed. "Taking an adult cell and reprogramming it is infinitely difficult," says Norton Zinder, a biologist at Rockefeller University in New York. "I don't think it will work in the laboratory.”

Zinder points out that The Lancet published a paper on 30 April by French scientists reporting the death of a cloned calf at seven weeks from anaemia. Its lymph nodes and spleen were not properly developed - an indication, he says, of the type of unexpected problem that could arise.

Investors apparently share some wariness about the new venture. Geron's stock closed at \$11.75 last Friday (7 May), down from $\$ 12.37$ on 3 May, the day the Roslin deal was announced. This was in contrast to last November, when the company's stock soared briefly to $\$ 24.50$ on the news of the stemcell isolation.

But others remain upbeat. "This deal will ensure that British scientists will play a key role in developing therapies that are potentially amongst the most exciting in human medicine," says Grahame Bullfield, director of the Roslin Institute.

Wilmut holds 83,000 shares in Geron Bio-Med, formerly Roslin Bio-Med. He says he was required by $3 \mathrm{i}$ Group, the original investor in Roslin Bio-Med, to purchase the shares as a condition of the launch of the company in 1998, to demonstrate his longterm commitment to its projects. The shares - not accessible to him for a year - were worth \$975,000 last Friday. "Who knows what they will be worth a year from now?" says Wilmut.
MeredithWadman 